\title{
A Japanese Robinson
}

\section{Kunio Tsunekawa}

My Asian mind suggests a vision of a post-modern aged Crusoe, one of the possible metamorphoses of this worldwide hero.

As it has been pointed out several times in the preceding texts, Robinson Crusoe predicts and foreshadows the modern age, the arriving capitalism notably, which means a conquest of nature by human beings, conquest, in other words, of the surrounding world by human wisdom and labour, by science and technology. But now we all know that science and technology will not necessarily ensure our happiness. We are aware of their destructive aspect as well as constructive ones.

In my vision of a post modern age Crusoe, he - Crusoe on his desert island - is no more this person who struggles and fights against nature with his science and technology. He appears as a simple human being sitting down on a long white beach, facing the everlasting waves and concentrating himself not on how to manage to survive but meditating how to empty himself, how to liberate himself from all kinds of human desires. He'll remain indefinitely in this posture. He wants to be united to the surrounding world, to be completely absorbed by nature into nature. Namely, he wants to become himself one of the elements of the world. Some day, say twenty-eight years later, a ship will appear on the horizon and approach the island. Sailors will find a mummy of Robinson Crusoe on the beach, facing the eternal ocean. And when one of the landing sailors touches him by inattention, the body - the mummy - will collapse down, be reduced to dusts or sands: the accomplishment of the postmodern Crusoe's last will. 